\title{
二次元矩形粗面乱流境界層における壁近傍流れの力学*
}

\author{
亀田 孝嗣 ${ }^{* 1}$, 望月 信介 ${ }^{* 2}$, 大坂 英雄 ${ }^{* 3}$

\section{The Flow Dynamics in Near-Wall Turbulence for the Boundary Layer over a Rough Surface with Two-Dimensional Square Ribs}

\author{
Takatsugu KAMEDA ${ }^{* 1}$, Shinsuke MOCHIZUKI and Hideo OSAKA \\ ${ }^{*}$ Kinki Univ. Dept. of Mechanical Engineering \\ Takaya-Umenobe 1, Higashihiroshima, Hiroshima, 739-2116 Japan
}

\begin{abstract}
LDV (Laser Doppler Velocimetry) measurement has been made near a rough surface to clarify the effect of momentum transports to pressure distribution acting on a roughness element. The measurements were performed for an equilibrium boundary layer developing over the rough surface that the roughness height is proportional to a streamwise distance. The momentum thickness and roughness Reynolds numbers are 6000 and 150, respectively. The accuracy of the mean velocities and turbulence in LDV measurement was checked by a momentum balance method and the estimated value was compared with the local skin friction coefficient measured by a direct measurement. Near the rough surface except for a cavity region, it was confirmed analytically and experimentally that the averaged shear stress profile given as a sum of apparent shear stress due to waviness of mean streamlines, Reynolds shear stress and viscous stress per a roughness pitch length is approximately equal to the wall shear stress. In the cavity region, the averaged shear stress profile can be expressed as a function of an integral of the mean pressure difference on downstream and upstream sidewalls of the cavity, and takes positive value except for the bottom region. In the present rough surface, the gradient of spatially-averaged Reynolds shear stress with respect to height will mainly contribute to the mean pressure difference on sidewalls in the cavity.
\end{abstract}

Key Words : Boundary Layer, Turbulent Flow, Shear Flow, LDV, Rough Wall

\section{1. 緒言}

著者ら(1)およびLeonaridiら (2)は, 粗さピッチ比 4 以下で配置された二次元矩形粗さ要素からなる粗面上の流れに おいてJackson ${ }^{(3)}$ が提案した粗面壁に作用する壁面抵抗の作用点位置と粗面乱流境界層の壁法則を議論する際に使 用される仮想壁面高さ位置 が一致することを明らかにした. さらに, 壁面抵抗の作用点位置が平均流および乱流 による運動量流束を粗さ底層内の粗さ要素間溝内部（以後, 溝内部と呼ぶ. ) 領域で積分した值と等しくなること を示した(1,3). 壁面抵抗の作用点位置と仮想壁面高さ位置が一致することは理論的背景のない実験的事実である が，壁面抵抗の作用点位置と壁近傍場の流れ構造が関連することは粗面流の特徵（例えば，二次元粗面流れに対 する粗さピッチ比の影響や二次元粗面流と三次元粗面流の違い）を説明する上で極めて興味深い事柄である.

これまでになされた粗面流の壁近傍場における流れ構造の特徵に関する研究について概観すると, 二次元粗面 流に関して粗さ要素後端から生じるはく離せん断層の発達 ${ }^{(4,5)}$, 溝内部渦の挙動 ${ }^{(6-8)}$ おび壁面抵抗 ${ }^{(5,9)}$ の観点から 議論されている.これらから, 粗さピッチ比の増大に伴いはく離せん断層は発達し, かつ溝内部流れパターン変 化の頻度が増加し, 溝内部流体と溝上方外部流体の運動量交換が強化されることが明らかにされた. また, 運動 量輸送の強化に伴って壁面抵抗は増加し, 圧力抵抗は壁面抵抗のほとんどを占めることが実験および直接数值計

* 原稿受付 2013 年 1 月 9 日

*1 正員, 近畿大学工学部（干739-2116 広島県東広島市高屋うめの辺 1 番）

*2 正員, 山口大学大学院理工学研究科（干755-8611 山口県宇部市常盤台 2-16-1）

*3 正員，フェロー，広島工業大学（下731-5193 広島県広島市佐伯区三宅 2-1-1）

E-mail:kameda@hiro.kindai.ac.jp 
算から報告された。一方，三次元粗面流に関して，Bandyopadhyayら ${ }^{(10)}$ は粗さ要素のスパン方向配置間隔に対し

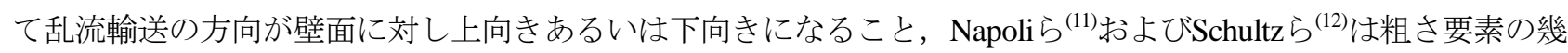
何パラメータとして有効傾斜（Effective Slope）を使用して粗面形状差による流れ特性（粗さ関数や壁面抵抗）の 変化を説明した．このように，流れ特性変化と粗さ要素幾何パラメータ（例えば，粗さピッチ比や有効傾斜）と の関係に関する調査はなされてきている. しかし, 本研究で着目する壁面抵抗の作用点位置は壁面抵抗の大きさ に加えて溝内部側壁面における圧力分布形状に依存するため, 粗面流の特徽差を説明する方法の一つとして圧力 分布形状と運動量輸送との関係を明らかにする必要があるものの，これに関する調査例は見当たらない.

そこで, 本研究では二次元矩形粗さ要素が粗さピッチ比 4 で配列された粗面上に発達する平衡境界層における 逆流を含む壁近傍場の運動量輸送に関する諸量（平均流運動量流束やレイノルズせん断応力）を計測するために レーザードップラー流速計（LDV）を使用する．LDVによる取得データと壁近傍場における運動方程式の主要項 から, 溝内部側壁面の圧力分布に対する運動量輸送の影響を調查し, 本粗面流の特徵を明らかにする.

\section{2. 実験装置および方法}

\section{$2 \cdot 1$ 実験装置および流れ場の概要}

実験に使用した風洞は既報 ${ }^{(13)}$ と同様である. 図 1 に流れ場，座標系および使用記号を示す．測定平板の上流部 は長さ $200 \mathrm{~mm}$ 滑面部を有しており，その先端ははく離防止のために角度 $17^{\circ}$ のシャープエッジ加工されてい る. 粗さ要素頂上面は滑面部からの流れを滑らかに流入させるために滑面部と平坦にしている，座標系は，測定 平板上流端のスパン中央位置に原点が置かれた右手直交座標系を採用した．流れ方向，高さ方向およびスパン方 向をぞれぞれ $x, y_{T}$ および $z$ とした. 測定粗面平板を構成する二次元矩形粗さ要素の高さ $k$ は, ゼ口圧力勾配下 で平衡境界層が実現可能となるように流れ方向距離 $x$ に対して比例 $\left(d k / d x=1.25 \times 10^{-3}, \quad x=0 \mathrm{~mm}\right.$ において $k=1.00 \mathrm{~mm}$ である. $)$ する. また, その配置間隔は粗さピッチ比 $P R(=(b+w) / k, \quad b$ は溝部幅およびwは粗さ 要素幅であり, $w=k$ とした. ) を 4 とした. なお, この粗面平板上で発達する乱流境界層において, 壁面摩擦 抵抗係数 $c_{f}$ が $x$ および運動量厚さ $\theta$ に基づくレイノルズ数 $R_{\theta}\left(=U_{1} \theta / v, U_{1}\right.$ は主流速度およびvは動粘度であ る.）に対してほぼ独立で $c_{f} \fallingdotseq 0.00826^{(13)}$ となり，そのほとんどが粗さ要素に作用寸る圧力抵抗係数 $c_{D}$ にっっ て生じる ${ }^{(1)}$. また, 外層の平均速度分布はレイノルズ数に独立となり, $c_{f}$ 值のみに依存することが確認されてい る ${ }^{(13)}$. 粗さ要素頂上面から壁面抵抗の作用点位置 までの距離を $d_{m}$ とし, その作用点位置を原点とした高さ方向 距離を $y \quad\left(=y_{T}+d_{m}\right)$ とする. 粗さ要素後端からの流れ方向距離を $x_{R E}$ とする. 測定部上壁面は可撓式であり, 圧力勾配を任意に調整可能である.

速度成分の測定には 2-Channel LDV システム（TSI IMF-750, 4WAr-Ion, 焦点距離 350mm）が使用された. LDV プローブから照射された 2 種類のレーザー光の波長は $514.5 \mathrm{~nm}$ （緑色）と 488nm（青色）であり，それらレ 一ザー光の交差部における楕円体の測定体積は短軸直径 $d_{s}=0.090 \mathrm{~mm}$ および長軸直径 $d_{l}=1.3 \mathrm{~mm}$ の大きさを有す る. なお，壁近傍場（溝内領域を除く.）において $d_{s}$ の乱れの積分長 $\ell$ と $k$ に対する比は 0.024 以下および $d_{l}$ に ついては 0.35 以下であった. 壁近傍場における二次元同時計測はレーザー光が粗さ要素壁面と干渉して測定が困
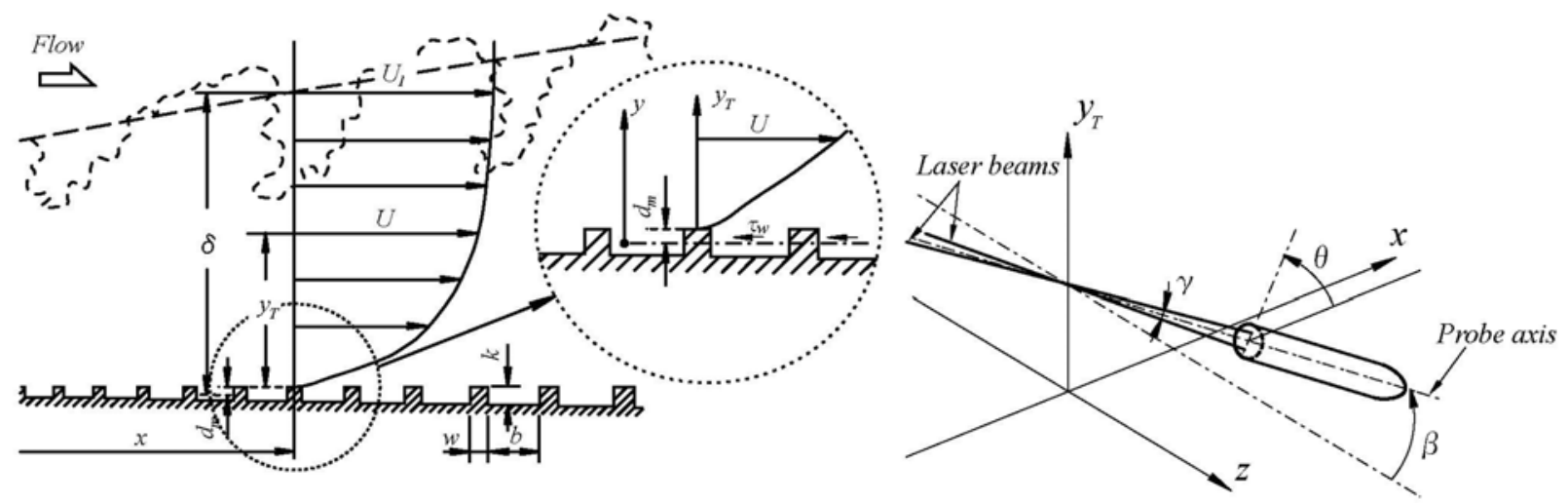

Fig.1 Flow field, nomenclature and coordinate system 


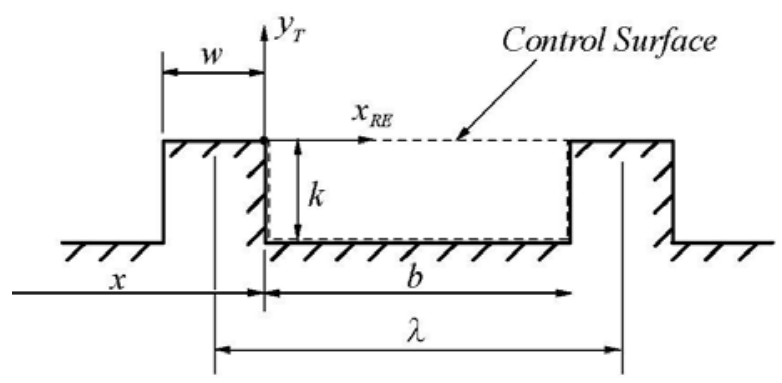

Fig.2 Control surface in a cavity region

難なため, 可能な限り粗さ要素近傍場の計測を行う測定法として, $2 \cdot 2$ 節で後述するように青色レーザー光のみ を利用した一次元計測による評価方法を採用した．この方法を採用することによって，データレートの向上と測 定時間の短縮も可能となり，測定值の信頼性の向上が期待できる. トレーサーに用いたオイル粒子は煙発生装置

(DANTEC SAFEX Fog Generator) により発生され, その平均粒径 $d_{o}$ は約 $1 \mu \mathrm{m}$ である. 測定部内の流れにオイ ル粒子を分散させるために，オイル粒子は送風機吸込み口から流入させた．オイル粒子の流れへの追従性はス卜 一クス数 $S_{t} \quad\left(=\rho_{o} r_{o}^{2} u_{\tau} /(\mu k), \rho_{o}\right.$ はオイル密度， $r_{o}$ はオイル粒子半径および $\mu$ は空気の粘性係数である．）か

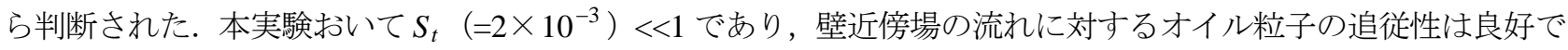
ある. サンプリング数は約 10 万個とし, データレートは境界層内において 500-1500Hzであった.

本実験においてゼ口圧力勾配下を実現するために, 主流中における $x$ および $z$ 方向の圧力係数 $C_{p}\left(=\left(P_{s}-P_{a}\right)\right.$ / $\left(1 / 2 \rho U_{1}^{2}\right) ， P_{s}$ は主流静圧， $P_{a}$ は大気圧および $\rho$ は空気密度である. ）が $0 \leq C_{p} \leq 0.005$ の範囲内に収まるよう に測定部上壁面の可撓式屋根を調整した．主流速度は，単位レイノルズ数 $U_{1} / v=6.24 \times 10^{5} \mathrm{~m}^{-1}$ となるように設定 された，測定は，平衡境界層となることが確認された $x \geq 2000 \mathrm{~mm}$ の範囲における $x=2180 \mathrm{~mm}$ 付近の粗さ要素一 ピッチの範囲で行われた．この流れ方向位置において， $R_{\theta}$ および粗さレイノルズ数 $k^{+}\left(=k u_{\tau} / v ， u_{\tau}\right.$ は摩擦速 度である.）はそれぞれ 6000 および 150 であった。

\section{$2 \cdot 2$ LDV の一次元計測による計測法およびその妥当性の検討}

LDV のプローブ軸を $\mathrm{z}$ 軸に平行にして二本に分光されたレーザー光を負の $\mathrm{z}$ 軸の方向に $\mathrm{x}-\mathrm{z}$ 平面に対して平行 に照射させるとき，干渉縞（フリンジ）は $y-z$ 平面に対して平行に形成される. このレーザー光の照射状態を基 準として,$\quad z$ 軸とプローブ軸のなすの角度を $\beta$, プローブ軸周りに反時計回りに回転させた角度を $\theta$ とする（図 1 参照)。いま，プローブ軸を $\beta$ だけ $z$ 軸に対して傾け，プローブ軸を $\theta$ だけ回転させた状態を考える， $x, y_{T} お$

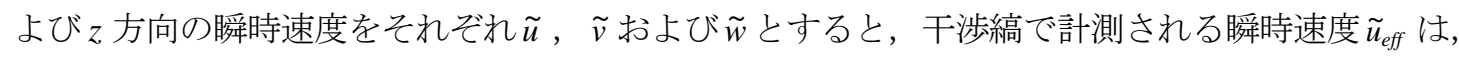

$$
\tilde{u}_{\text {eff }}=\tilde{u} \cos \theta+\tilde{v} \sin \theta \cos \beta-\tilde{w} \sin \theta \sin \beta
$$

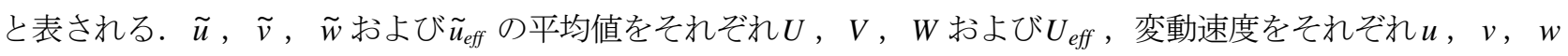
および $u_{e f f}$ とすると, 二次元流における平均速度および二乗平均変動速度の応答方程式は式（1）から

$$
\begin{aligned}
& \frac{U_{\text {eff }}}{\overline{u_{\text {eff }}^{2}}}=\frac{U}{u^{2}} \cos \theta+V \sin \theta \cos \beta \\
& \cos ^{2} \theta+\overline{v^{2}} \sin ^{2} \theta \cos ^{2} \beta+\overline{w^{2}} \sin ^{2} \theta \sin ^{2} \beta+2 \overline{u v} \sin \theta \cos \theta \cos \beta
\end{aligned}
$$

が導かれる.ここで, 平均速度および変動の二次モーメント量に対する $\beta$ の影響についてみる. $U$ および $\overline{u^{2}}$ は $\beta$ $\neq 0$ および $\theta=0^{\circ}, V$ および $v^{2}$ は $\beta \neq 0$ および $\theta=90^{\circ} ， \overline{u v}$ は $\beta \neq 0$ および $\theta= \pm \alpha \quad(\alpha \neq 0)$ の状態で計測する. これらの状態から, 平均速度および二乗平均変動速度はそれぞれ

$$
\begin{aligned}
& U=\left.U_{\text {eff }}\right|_{\beta \neq 0 \text { and } \theta=0}, \quad V=\frac{\left.U_{\text {eff }}\right|_{\beta \neq 0 \text { and } \theta=90}}{\cos \beta} \\
& \overline{u^{2}}=\left.\overline{u_{\text {eff }}^{2}}\right|_{\beta \neq 0 \text { and } \theta=0}, \overline{v^{2}}=\frac{\left.\overline{u_{\text {eff }}^{2}}\right|_{\beta \neq 0 \text { and } \theta=90}}{\cos ^{2} \beta\left(1+\frac{\overline{w^{2}}}{\overline{v^{2}}} \tan ^{2} \beta\right)}, \overline{u v}=\frac{\left.\overline{u_{\text {eff }}^{2}}\right|_{\beta \neq 0 \text { and } \theta=+\alpha}-\left.\overline{u_{\text {eff }}^{2}}\right|_{\beta \neq 0 \text { and } \theta=-\alpha}}{4 \sin \theta \cdot \cos \theta \cdot \cos \beta}
\end{aligned}
$$




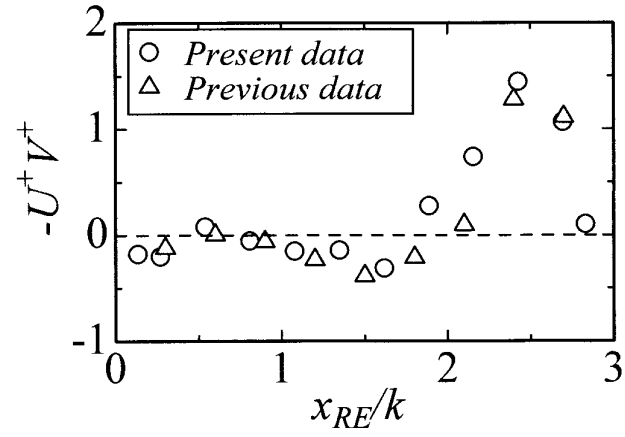

(a) Mean flow momentum flux

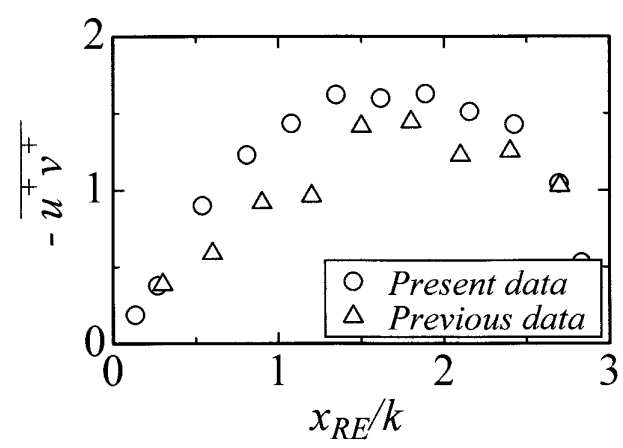

(b) Reynolds shear stress

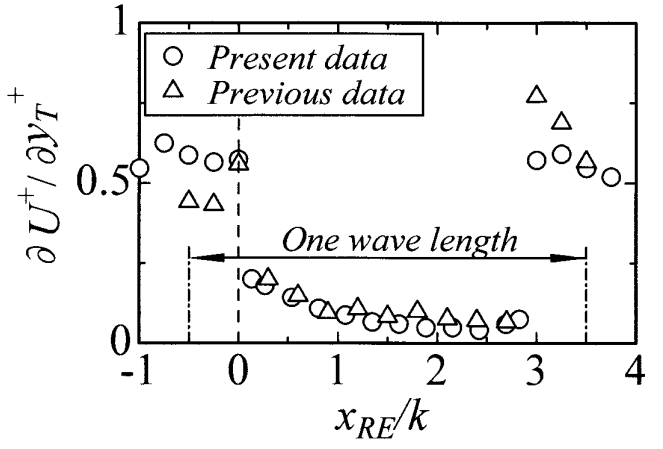

(c) Viscous shear stress

Fig.3 Mean velocities and Reynolds shear stress profiles on $y_{T}=0 \mathrm{~mm}$ plane between roughness elements

となる.これらの式から， $\beta$ は $V, \overline{v^{2}}$ および $\overline{u v}$ に影響を与えることが分かる. 通常の乱流境界層では $\overline{w^{2}} / \overline{v^{2}} \approx 2^{(14)}$ であること，および本実験では $\beta=4^{\circ} \quad$ （レーザー光の交差角 $\gamma$ の半值）の状態で計測を行うことを考慮すると， 式（4）中の分母に含まれる $\beta$ の影響は $1 \%$ 以であるので,

$$
\left.V \cong U_{\text {eff }}\right|_{\beta \neq 0 \text { and } \theta=90},\left.\overline{v^{2}} \cong \overline{u_{e f f}^{2}}\right|_{\beta \neq 0 \text { and } \theta=90}, \overline{u v} \cong \frac{\left.\overline{u_{\text {eff }}^{2}}\right|_{\beta \neq 0 \text { and } \theta=+\alpha}-\left.\overline{u_{\text {eff }}^{2}}\right|_{\beta \neq 0 \text { and } \theta=-\alpha}}{4 \sin \theta \cdot \cos \theta}
$$

として評価を行う。なお，式（5）における $\overline{u v}$ 中の $\alpha$ 值は粗さ底層内の流れが高乱れであること，溝部側壁およ び溝部底面近傍計測を考慮して $30^{\circ}$ と $20^{\circ}$ （溝内部側壁近傍のみ）とした。

測定值の妥当性は，粗さ要素一ピッチ間を検査領域（図 2 参照）として運動量変化と粗さ要素一ピッチ間に作 用する壁面抵抗の関係式 (6) ${ }^{(5)}$ から評価された.

$$
c_{f}\left(=\frac{D}{1 / 2 \rho U_{1}^{2} \lambda}\right)=\left.\frac{2}{U_{1}^{2} \lambda} \int_{0}^{b}(-U V)\right|_{y_{T}=0} d x_{R E}+\frac{2}{U_{1}^{2} \lambda} \int_{0}^{b}(-\overline{u v})_{y_{T}=0} d x_{R E}+\left.\frac{2}{U_{1}^{2} \lambda} \int_{-k / 2}^{b+k / 2} v \frac{\partial U}{\partial y_{T}}\right|_{y_{T}=0} d x_{R E}
$$

式（6）中右辺第一項～第三項の被積分項の結果を図 3 （a）～（c）にそれぞれ示寸. 平均速度勾配 $\partial U / \partial y_{T}$ は二 次精度の差分法により評価された。縦軸の $-U^{+} V^{+},-\overline{u^{+} v^{+}}$および $\partial U^{+} / \partial y_{T}^{+}$は摩擦速度 $u_{\tau}$ で無次元化された $-U V,-\overline{u v}$ おびv $\partial U / \partial y_{T}$ 值であり，横軸の $x_{R E}$ は $k$ で無次元化された. なお， $y^{+}$は $y^{+}=y u_{\tau} / v$ である. ま た，図 3 中には $R_{\theta}=700$ および $k^{+}=85$ の下で $P R=4$ （ただし， $k=$ const.である. ）の二次元矩形粗面上で発達する 境界層の結果 ${ }^{(5)}$ も合わせて示す．無次元化された $-U V ，-\overline{u v}$ およびv $\partial U / \partial y_{T}$ 值の本結果は既報の結果 ${ }^{(5)}$ と良好 に対応している. 図 3 の結果に基づいて評価された式 (6) 中右辺第一項〜第三項の值はそれぞれ $0.00139,0.00713$ および 0.00190 あった。それらの和（0.01042） は既報 ${ }^{(13)} の$ 浮動片要素応力直接測定から評価された $c_{f}$ 值 $\left(c_{f}=0.00826\right)$ に対して $26.2 \%$ 不釣合いとなった。 ここで, LDV計測による $c_{f}$ 值の不確かさ $\Delta c_{f} / c_{f}$ を見積も る. 式 (6) 中被積分項の $-U V,-\overline{u v}$ および $\partial U /\left.\partial y_{T}\right|_{y_{T=0}}$ の不確かさは, プローブ軸傾斜角 $\beta$, 測定データ数, 


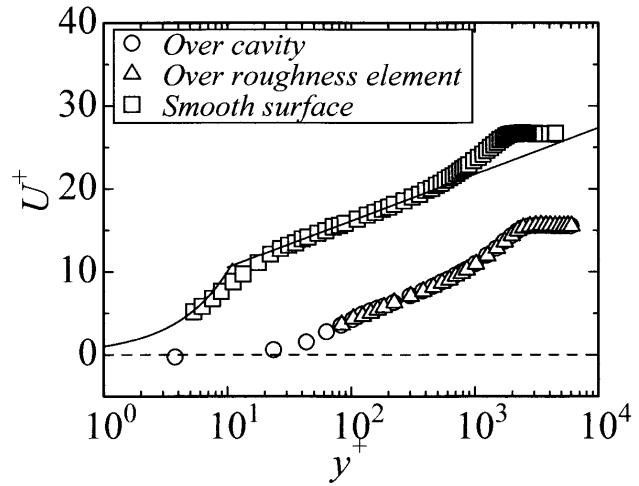

(a)Logarithmic mean velocity profile

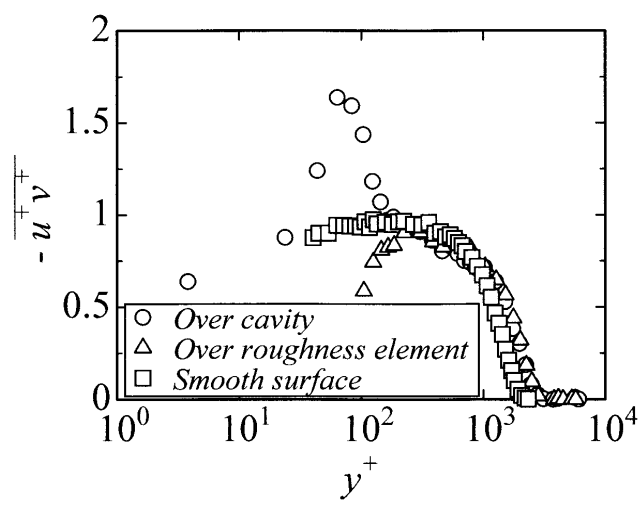

(b) Reynolds shear stress profiles normalized with inner variables

Fig.4 Streamwise mean velocity and Reynolds shear stress profiles

測定位置設定や差分精度に起因する要因により評価された。 $-U V$ の不確かさ $\Delta(-U V) /(-U V),-\overline{u v}$ の不確かさ $\Delta(-\overline{u v}) /(-\overline{u v})$ および $\partial U /\left.\partial y_{T}\right|_{y_{T}=0}$ の不確かさ $\Delta\left(\partial U /\left.\partial y_{T}\right|_{y_{T}=0}\right) /\left(\partial U /\left.\partial y_{T}\right|_{y_{T}=0}\right)$ は，それぞれ $0.3,17.4$ および $36.0 \%$ であった. なお, $\Delta\left(\partial U /\left.\partial y_{T}\right|_{y_{T}=0}\right) /\left(\partial U /\left.\partial y_{T}\right|_{y_{T}=0}\right)$ 值が大きくなった理由は, 差分間隔 $\Delta y \quad(=0.20 \mathrm{~mm})$ とそれに対

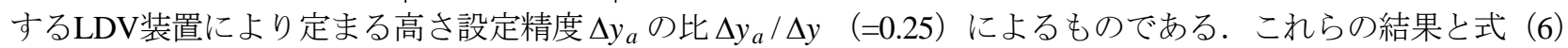
中の $U_{1}, b ， \lambda$ およびvの不確かさ（それぞれ $0.3 ， 0.4 ， 0.3$ および $0.4 \%$ ）を考慮して， $\Delta c_{f} / c_{f}=37.0 \%$ と見積 もられた. 一方, 直接測定された $c_{f}$ 值の不確かさは $c_{f}$ 值の算出式

$$
c_{f}=\frac{F}{1 / 2 \cdot \rho U_{1}^{2} A}
$$

に基づき, 既報 ${ }^{(13)}$ の結果から再評価された。ここで， $F$ は浮動片要素に作用する力および $A$ は浮動片要素表面積 である． $F$ の不確かさ $\Delta F / F \quad(=9.2 \%)$ は較正曲線のもつ不確かさ，浮動片要素と周囲板の隙間（ギャップ）の 存在によって生じる二次的な力による不確かさおよび浮動片要素と周囲板との高さの差（ミスアラインメント） による不確かさを考慮し， $A ， U_{1}$ および $\rho$ の不確かさ $(=0.3 ， 0.3$ および $0.4 \%)$ を用いて $\Delta c_{f} / c_{f}=9.2 \%$ と見積も られた，両者の合成不確かさ $37.2 \% に$ 対して両者の差（26.2\%）は小さいので，両者の值の有意差は小さいと考え られる．以上より，本LDVの測定法による計測值は後述の議論に対して妥当と判断した.

\section{3. 結果および考察}

\section{$3 \cdot 1$ 境界層断面内の分布}

粗さ要素近傍領域に着目する前に, 粗さ要素に相対的な位置の差による分布の変化が生じる範囲を代表断面

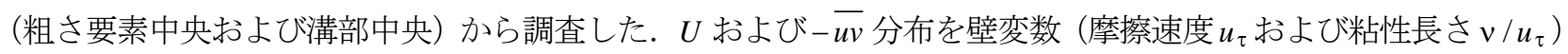
で無次元化した $U^{+}\left(=U / u_{\tau}\right)$ および $-\overline{u^{+} v^{+}}\left(=-\overline{u v} / u_{\tau}^{2}\right)$ 分布を図 4 (a) および (b) に示す. $d_{m}$ 值は既報 ${ }^{(1)}$ で 評価された值 $\left(d_{m} / k=0.43\right)$ を， $u_{\tau}$ 值は直接測定により評価された $c_{f}$ 值 ${ }^{(13)}$ から算出された值を使用した. なお, 図 4 (a) および (b) 中には滑面流（ $R_{\theta}=6230 ）$ の結果 ${ }^{(14)}$ も合わせて示す. 図 4 (a) の対数速度分布についてみ る. 本粗面流の結果は滑面流の分布に対して下方に平行移動しており，その移動量の差（粗さ関数 $\Delta U / u_{\tau} ）$ は既 報の結果(13) と良好に一致していた．粗さ要素に相対的な位置の差による分布の変化は，粗さ要素上の測定最下限 高さ位置 $\left(y_{T}=0.5 \mathrm{~mm}\right)$ である $y^{+} \fallingdotseq 80$ 付近までほとんどみられない. 一方，図 4 (b) の- $\overline{u^{+} v^{+}}$分布についてみ ると, 粗さ要素に相対的な位置の差による影響が $y^{+} \fallingdotseq 300$ 付近まで生じている. 粗さ要素上の $-\overline{u^{+} v^{+}}$值は壁面 による滑りなしの影響によって $y^{+}$の減少に伴い減少するが, 溝部中央部では粗さ要素後端から形成されるはく離 せん断層により $y^{+} \fallingdotseq 60\left(y_{T} \fallingdotseq 0 \mathrm{~mm}\right)$ 付近まで増加（ピーク值は 1.64）し，その後減少する. 本報告では, $y^{+}<300$

$\left(y_{T} / k<1.62\right)$ の範囲を粗さ底層（Roughness Sublayer）と呼ぶことにする．なお，対数速度分布が成立する上限 高さ以下 $\left(y^{+}<600\right)$ の内層領域の $y^{+}>300$ の範囲において, $-\overline{u^{+} v^{+}}$分布は滑面流の結果と良好に一致している. 


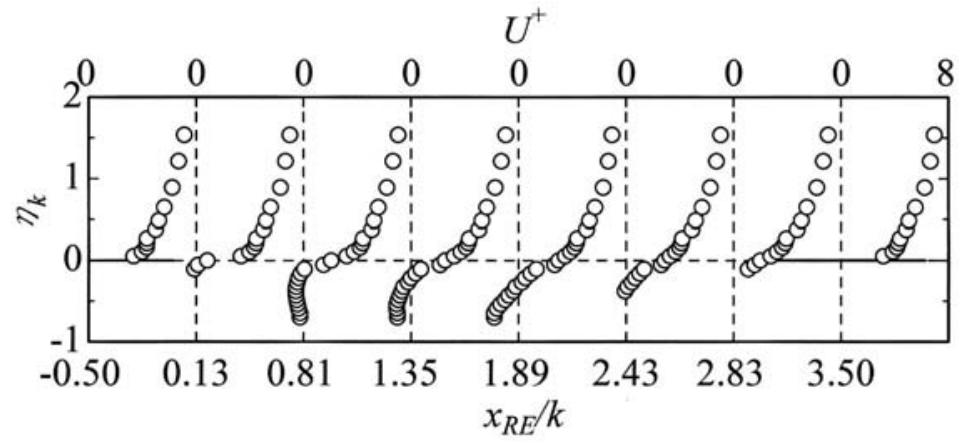

(a)Streamwise mean velocities

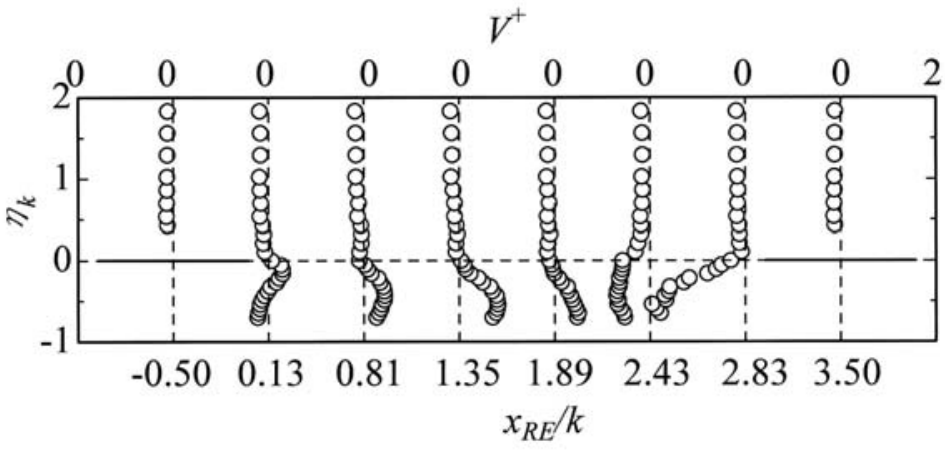

(b)Normal mean velocity profiles

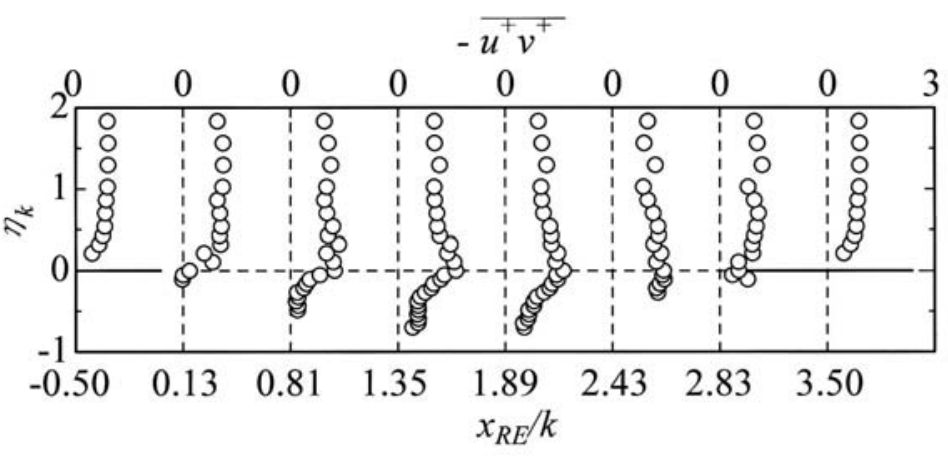

(c)Reynolds shear stress profiles

Fig.5 Mean velocities and Reynolds shear stress profiles in the roughness sublayer

\section{$3 \cdot 2$ 粗さ底層内の分布}

式 (6) から $c_{f}$ 值に直接関係する $U^{+}, V^{+}\left(=V / u_{\tau}\right)$ および $-\overline{u^{+} v^{+}}$分布について粗さ要素一ピッチ間におけ る 8 断面の分布をそれぞれ図 5 (a) 〜 (c) に示寸. 縦軸の $\eta_{k}$ は $\eta_{k}=y_{T} / k$ である. 図示した高さ方向範囲は $\eta_{k}<2.0$ であり，粗さ底層は $\eta_{k}<1.62$ の範囲に対応する．図 5 中の実線で描かれた横線は粗さ要素部を意味する. 破線で 描かれた横線は $\eta_{k}=0$, 一方綐線は図 5 (a) では $U^{+}=0$, 図 5 (b) では $V^{+}=0$ および図 5 (c) では $-u^{+} v^{+}=0$ であ る. 図 5 (a) の $U^{+}$分布についてみる. 粗さ要素上の $U^{+}$分布では, $\eta_{k}=0$ における平均速度勾配 $\partial U^{+} / \partial \eta_{k}$ の值 が大きい. 溝部の $\eta_{k}=0$ における $U^{+}$值はせん断応力による連行作用により粗さ要素後端 $\left(x_{R E} / k=0\right.$ で $\left.U^{+}=0\right)$ から $x_{R E} / k$ の増加に伴い増加し, その後下流側粗さ要素の存在による逆圧力勾配の影響で減少する. さらに, 連 行作用によりはく離せん断層が形成されるとともに， $U^{+}>0$ の領域が溝内部領域に拡大している．また，溝内部 下方領域には逆流 $\left(U^{+}<0\right)$ が存在する. これは， $\eta_{k}=0$ におけるせん断応力を駆動力とした時計周りの循環渦が 形成されていることを意味する．事実，本実験と同じ粗さピッチ比を有する粗面流の可視化実験 ${ }^{(8)}$ から循環渦が 確認されている. なお， $\eta_{k}=0$ 付近における $U^{+}$分布の不連続性は, レーザー交差部の高さ設定精度に起因して生 じたものである. 図 5 (b) の $V^{+}$分布は，循環渦の回転方向に対応した分布形状であり，溝内部下流側では他の 領域と比較して強い下向きの流れとなっている. 図 5 (c) の $-\overline{u^{+} v^{+}}$分布についてみる. 粗さ要素上の $-\overline{u^{+} v^{+}}$值 は, 壁面の存在により $\eta_{k} \rightarrow 0$ に伴って $-\overline{u^{+} v^{+}} \rightarrow 0$ となる挙動である. 溝部上において, 溝部上流側粗さ要素近傍 
$\left(x_{R E} / k=0.13\right) の-\overline{u^{+} v^{+}}$分布は粗さ要素上のそれと同様な分布形状であるが, 下流に行くに従って $\eta_{k}=0$ 近傍の $-\overline{u^{+} v^{+}}$值ははく離せん断層の発達に伴い増加し, 分布の幅も拡がっている. さらに下流にいくと, $-\overline{u^{+} v^{+}}$值は 減少する.これは下流側粗さ要素への流れの衝突によるはく離渦の分断や壁面上の滑りなし条件によるものと推 測される. 以上より, 粗さ要素近傍の $U^{+}, V^{+} お よ ひ ゙-\overline{u^{+} v^{+}}$分布は粗さ要素に相対的な位置によって異なる分 布形状をしているが, 考察をより容易にするために粗さ要素一ピッチ当たりの平均の流れ構造について議論する.

\section{$3 \cdot 3$ 粗さ要素ーピッチ当たりの空間平均流れ構造}

ある時間平均值 $(*)$ の粗さ要素一ピッチ当たりの空間平均值 $\langle(*)\rangle$ を式（8）で定義する.

$$
\left.\langle(*)\rangle \equiv \frac{1}{\lambda} \int_{-k / 2}^{b+k / 2}{ }^{*}\right) d x_{R E}
$$

時間平均値 $(*)$ と空間平均值 $\langle(*)\rangle$ 差である空間変動值を $(*)^{\prime}$ とすると,

$$
(*)=\langle(*)\rangle+(*)^{\prime}
$$

の関係式で与えることができる. 式（9）を連続の式および $x$ 方向レイノルズ方程式中のレイノルズ応力成分を除 く全ての時間平均量に適用し, 空間平均操作 (粗さ要素 1 ピッチ) を行う. 式 (8) で定義される空間平均值は溝 内部領域を除く粗さ底層に適用し，以下の仮定が成立するものとする.

(1)空間平均值 $\langle(*)\rangle$ は流れ方向距離に対して連続で, かつ一定となる.

(2)時間平均值 $\left(^{*}\right)$ と空間平均值 $\langle(*)\rangle$ との差である空間変動值 $(*)^{\prime}$ は, 溝内部領域を除いて粗さ要素に対応して周期 的に変化する.

実際には, 粗さ要素高さ $k$ および境界層厚さ $\delta$ が流れ方向に変化するため, 着目粗さ要素一ピッチ間の $\langle(*)\rangle$ 值と 隣接粗さ要素一ピッチ間のそれは連続とならず， $\left({ }^{*}\right)^{\prime}$ 值も周期的に変化しない. しかし， $k$ および $\delta$ の流れ方向 変化率 (本粗面流では, $d k / d x=1.25 \times 10^{-3}$ および $d \delta / d x=2.76 \times 10^{-2}$ である.) が小さいとき, 粗さ要素数ピッチ の範囲で $\langle(*)\rangle$ 值は一定， $(*)^{\prime}$ 值は周期的に変化すると仮定しても差し支えないであろう。なお，粗さ要素高さ一 定の二次元矩形粗面上の流れにおいて，(*) 值は粗さ要素に対応して周期的に変化することが実験的に確かめら れている(15,16). 着目粗さ要素一ピッチ間において, 連続の式から

$$
\frac{d\langle V\rangle}{d y_{T}}=0 \quad \text { and } \quad \frac{\partial U^{\prime}}{\partial x}+\frac{\partial V^{\prime}}{\partial y_{T}}=0
$$

が導き出される． $y_{T}=0$ （溝部開口面）では流れが二次元流であることを考慮すれば $\langle V\rangle=0$ となるので，粗さ底 層の横断面内で $\langle V\rangle=0$ となる. これに関して, 溝内部領域を除く粗さ底層内において $\langle V\rangle /\langle U\rangle$ 值は 3.3\%以下であ った. 同様に, $x$ 方向レイノルズ方程式は,

$$
0=-\frac{1}{\rho}\left\langle\frac{\partial P^{\prime}}{\partial x}\right\rangle-\frac{d\left\langle U^{\prime} V^{\prime}\right\rangle}{d y_{T}}-\frac{d\langle\overline{u v}\rangle}{d y_{T}}+v \frac{d^{2}\langle U\rangle}{d y_{T}^{2}}
$$

と表される. 対象とする領域において第一項は $P^{\prime}$ 值の周期性によりゼロとなるので, 式 (11) は式 (12) となる.

$$
0=\frac{1}{\rho} \frac{d\langle\tau\rangle}{d y_{T}}, \text { where } \frac{\langle\tau\rangle}{\rho}=v \frac{d\langle U\rangle}{d y_{T}}-\langle\overline{u v}\rangle-\left\langle U^{\prime} V^{\prime}\right\rangle
$$

$\langle\tau\rangle$ は空間平均せん断応力を意味する. 〈 $\langle$ の右辺第一項は空間平均粘性応力, 第二項は空間平均レイノルズ応力

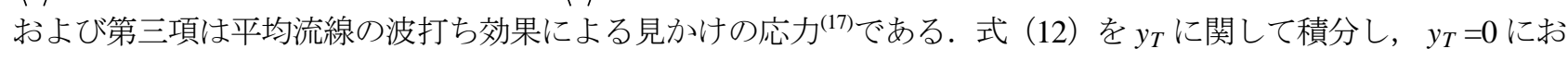
いて $\langle\tau\rangle$ 值が粗面平板に作用する壁面せん断力の粗さ要素一ピッチ当たりの平均值 $\left\langle\tau_{w}\right\rangle \quad\left(=\rho u_{\tau}^{2}\right)$ と等しいこと を考慮すると， 


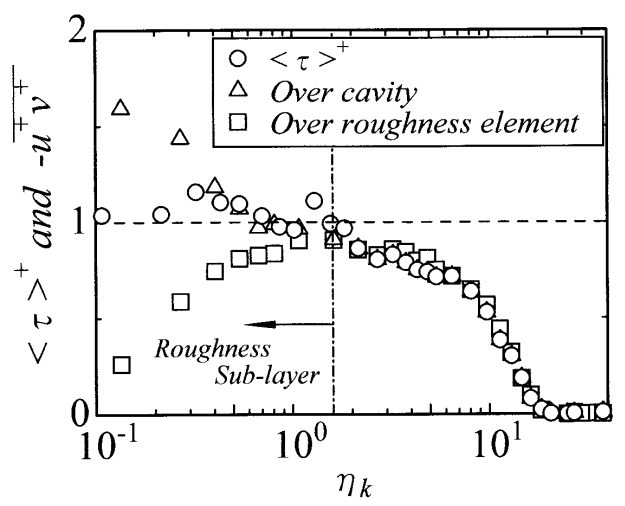

Fig.6 Averaged Reynolds shear stress profile except for a cavity region

$$
\langle\tau\rangle=\left\langle\tau_{w}\right\rangle
$$

の関係式が導かれる．故に，〈て〉值は溝内部領域を除く粗さ底層内で一定となることが期待される．そこで，図 5

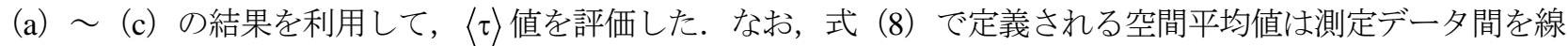
形補間して, 空間平均粘性応力は二次精度の差分法により算出された. 図 6 に摩擦速度 $u_{\tau}$ で無次元化した $\langle\tau\rangle^{+}$ $\left(=\langle\tau\rangle /\left(\rho u_{\tau}^{2}\right)\right)$ 分布を示す. 図 6 中には, 溝内部領域を除く境界層内の $\langle\tau\rangle^{+}$分布を示す. なお, 粗さ底層より 上方の領域では境界層の発達および粗さ要素に対応した分布の変化は小さいとして, $\langle\tau\rangle^{+}=-\overline{u^{+} v^{+}}\left(-\overline{u^{+} v^{+}}\right.$值 は溝部中央における值を代表する.） とした．図６中には，図４（b）の溝部中央および粗さ要素中央部の結果 も合わせて示す．横軸は，粗さ要素高さで無次元化した高さ方向距離 $\eta_{k}$ である. 図 4 (b) で述べたように粗さ 要素中央および溝部中央断面の $-\overline{u^{+} v^{+}}$分布は粗さ底層内で $\eta_{k}$ に対して増加あるいは減少傾向を示すが, 式 (12) で定義した $\langle\tau\rangle^{+}$值は $\eta_{k}$ に対する依存性は弱く, $\left\langle\tau_{w}\right\rangle$ とほぼ等しい. 従って, 上述の二つの仮定は妥当と考えら れる. なお，図示していないが， $\eta_{k}=0$ において空間平均粘性応力および平均流線の波打ち効果による見掛けの 応力は $\left\langle\tau_{w}\right\rangle$ に対してそれぞれ $12.1 \%$ よび $8.8 \%$ の寄与であった.

次に, 溝内部領域について考察する. 溝内部領域において空間平均操作を行う積分範囲は $x_{R E}=0 \sim b$ （溝部の 範囲）であるので，空間平均值は式（8）と区別するために，

$$
\langle(*)\rangle_{c} \equiv \frac{1}{\lambda} \int_{0}^{b}(*) d x_{R E}
$$

と表すことにする，空間変動值は，式（9）中の $\langle(*)\rangle を\langle(*)\rangle_{c}$ で置き換えた関係式で与える，溝内部側壁面におけ る境界条件を考慮して， $x$ 方向レイノルズ方程式に対して空間平均操作を行うと，

$$
0=-\frac{1}{\rho}\left\langle\frac{\partial P^{\prime}}{\partial x}\right\rangle_{c}-\frac{d\left\langle U^{\prime} V^{\prime}\right\rangle_{c}}{d y_{T}}-\frac{d\langle\overline{u v}\rangle_{c}}{d y_{T}}+\lambda_{s} v \frac{d^{2}\langle U\rangle_{c}}{d y_{T}^{2}}
$$

が得られる. 式 (15) 中, $\lambda_{s}(=b / \lambda)$ は既報(18)で定義した粗さ密度である. 溝内部領域における空間平均せん 断応力を $\langle\tau\rangle_{c}$ とし,

$$
\frac{\langle\tau\rangle_{c}}{\rho}=\lambda_{s} v \frac{d\langle U\rangle_{c}}{d y_{T}}-\langle\overline{u v}\rangle_{c}-\left\langle U^{\prime} V^{\prime}\right\rangle_{c}
$$

と表す．式（16）を式（15）に代入すると, 
Table 1 Experimental conditions of quoted data in Figures 7 and 8.

\begin{tabular}{|c|c|c|c|c|c|}
\hline Source & $w / \lambda(=P R)$ & $R_{\theta}$ & $k^{+}$ & $R_{P}$ & $\left\langle\tau_{0 v}\right\rangle_{w}^{+}$ \\
\hline \hline Previous data $^{(1)}$ & 4 & 6000 & 150 & 0.93 & 0.57 \\
\hline Osaka et al. $^{(19)}$ & 2 & 5000 & 134 & 0.30 & 1.66 \\
\hline \multirow{2}{*}{ Schofield et al. $^{(20)}$} & 2 & - & - & 0.04 & - \\
\cline { 2 - 6 } & 4 & - & - & 0.91 & - \\
\hline Kameda et al. $^{(15)}$ & 4 & 5870 & 134 & 0.94 & - \\
\hline
\end{tabular}

[ - : Unknown value]

$$
\frac{d\langle\tau\rangle_{c}}{d y_{T}}=\left\langle\frac{\partial P^{\prime}}{\partial x}\right\rangle_{c}
$$

となる. 式（17）を $y_{T}=-a \sim 0$ の範囲（ここで， $a$ は $0 \leq a \leq k$ の範囲における任意の值である.） で積分する と, 溝内部の任意高さ位置における $\langle\tau\rangle_{c}$ は,

$$
\langle\tau\rangle_{c}=\left\langle\tau_{0}\right\rangle_{c}-\int_{-a}^{0}\left\langle\frac{\partial P^{\prime}}{\partial x}\right\rangle_{c} d y_{T}
$$

と表される. $\left\langle\tau_{0}\right\rangle_{c}$ は $y_{T}=0$ における $\langle\tau\rangle_{c}$ であり, $\left\langle\tau_{w}\right\rangle$ から粗さ要素上の粘性応力を差し引いた值と等しく, 粗 さ要素上における粗さ要素幅当りの平均粘性応力を $\left\langle\tau_{0 v}\right\rangle_{w}$ とすると,

$$
\left\langle\tau_{0}\right\rangle_{c}=\left\langle\tau_{w}\right\rangle-\frac{w}{\lambda}\left\langle\tau_{0 v}\right\rangle_{w}
$$

で与えられる. 式（18）中の被積分項は

$$
\left\langle\frac{\partial P^{\prime}}{\partial x}\right\rangle_{c}=\frac{1}{\lambda} \int_{0}^{b} \frac{\partial P^{\prime}}{\partial x} d x_{R E}=\frac{\Delta P^{\prime}}{\lambda} \text {, where } \Delta P^{\prime}=P_{u}^{\prime}-P_{d}^{\prime}
$$

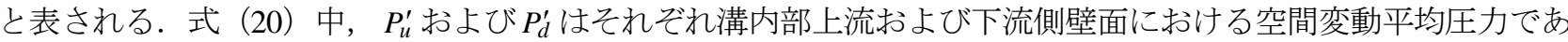
る. それらの圧力差 $\Delta P^{\prime}$ は粗さ要素一ピッチに作用する圧力抵抗 $F_{P}$ に関係するので, $F_{P}$ に基づく速度尺度 $u_{p}$ を 式（21）のように定義する.

$$
u_{p} \equiv \sqrt{\frac{F_{P}}{\rho k}}
$$

定義した $u_{p}$ によって無次元化した $\Delta P^{\prime}$ を無次元圧力差 $\Delta C_{P^{\prime}}$ （式（22））と表す.

$$
\Delta C_{P^{\prime}}=\frac{\Delta P^{\prime}}{1 / 2 \cdot \rho u_{P}^{2}}
$$

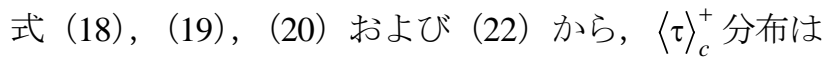

$$
\langle\tau\rangle_{c}^{+}=1-\frac{w}{\lambda}\left\langle\tau_{0 v}\right\rangle_{w}^{+}-\frac{1}{2} R_{P} \int_{-\eta}^{0} \Delta C_{P^{\prime}} d \eta_{k} \text {, where } \eta=\frac{a}{k}
$$




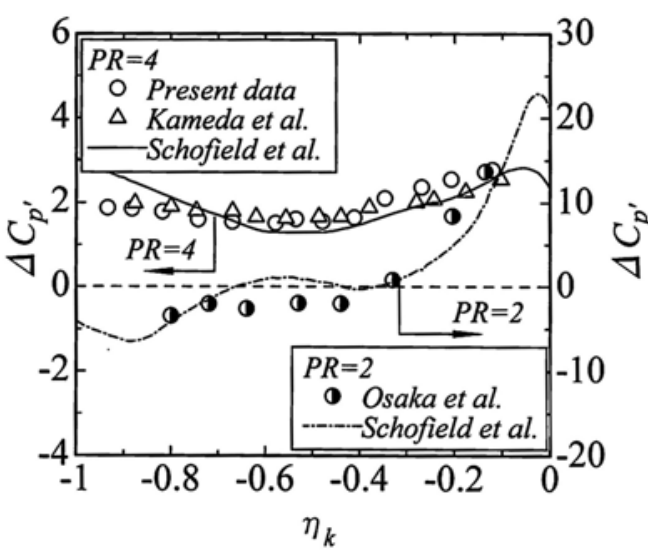

Fig.7 Pressure difference normalized with the velocity based on the pressure drag

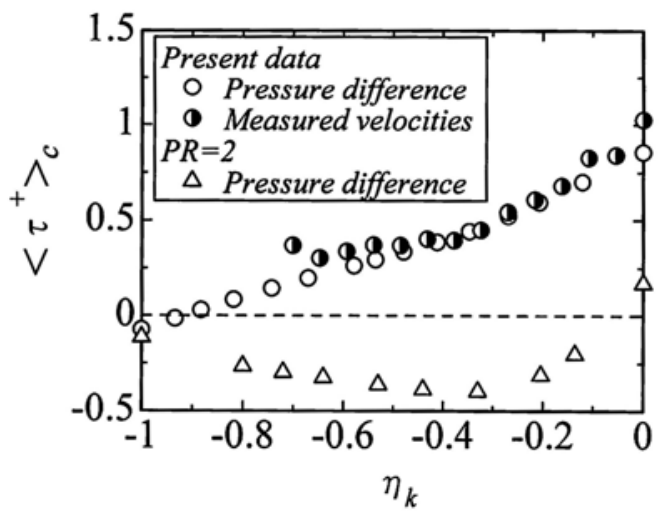

Fig.8 Averaged shear stress profiles in a cavity

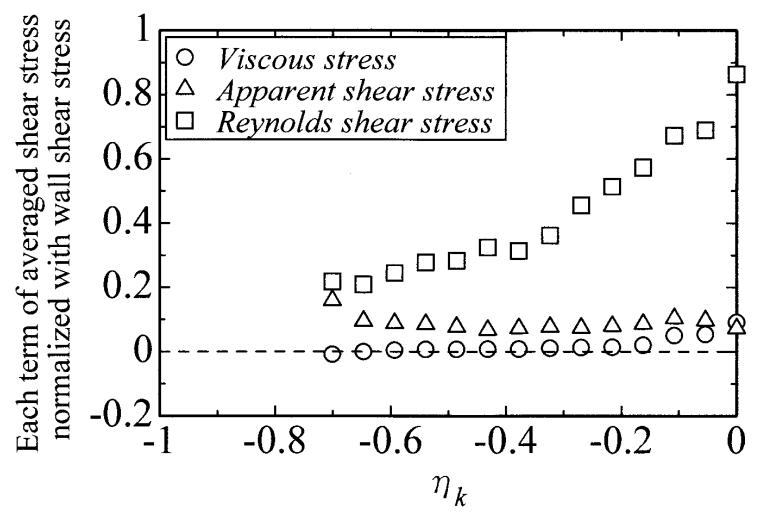

Fig.9 Each term of averaged total shear stress in a cavity

と書き直せる. なお，式（23）は式（13）と $y_{T}=0$ で連続にならない. 式 (23) 中, $R_{P}$ は $R_{P}=\left(F_{P} / \lambda\right) /\left\langle\tau_{w}\right\rangle$ であり，粗さ要素一ピッチ当りの壁面抵抗に対する圧力抵抗の比を意味する．ここで， $\Delta C_{P^{\prime}}$ 值の $\eta_{k}$ に対する変

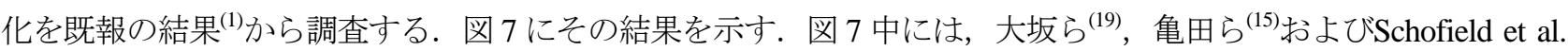

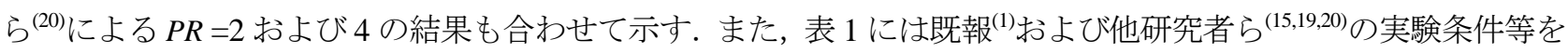
示しており，表 1 中の $R_{P}$ 值は溝内部側壁面の圧力分布を線形補間して得られた $F_{P}$ 值を用いて評価された. 図 7 より, $\Delta C_{P^{\prime}}$ 分布は $P R$ 值によって異なる分布形状である. $P R$ 值が同值であるとき, $\Delta C_{P^{\prime}}$ 分布はほぼ一致した 分布傾向を示している. 表 1 において実験条件が明らかな結果についてみると, $P R=4 の \Delta C_{P^{\prime}}$ 值は溝内部底面 $\left(\eta_{k}=-1\right)$ から $\eta_{k}=0.5$ 付近まで正でほぼ一定（ $\Delta C_{P^{\prime}} \fallingdotseq 1.74 ）$ であり, その後 $\eta_{k}$ が増加すると粗さ要素頂上部 $\left(\eta_{k}=0\right)$ に向かってわずかに増加する. 一方, $P R=2$ では溝内部下方領域（ $\eta_{k}=-1 \sim-0.5 ）$ においてほぼ一定と なる $\Delta C_{P^{\prime}}$ 值は負值 $\left(\Delta C_{P^{\prime}} \fallingdotseq-2.41\right)$ となり, 溝内部上方領域 $\left(\eta_{k}=-0.5 \sim 0\right)$ における值の増加は $P R=4$ に比べ著 しい.この結果より, 圧力抵抗に寄与寸る $\Delta C_{P^{\prime}}>0$ となる領域は, $P R=4$ では溝部高さの全領域が，一方 $P R=2$ では溝内部上方領域のみとなることが分かる. $\Delta C_{P^{\prime}}$ 分布とせん断応力 $\langle\tau\rangle_{c}^{+}$分布の関係を調べるために, 式 (23) に基づいて $\langle\tau\rangle_{c}^{+}$分布を $\Delta C_{P^{\prime}}$ 分布から評価する. $\langle\tau\rangle_{c}^{+}$值の評価の際に用いた $\Delta C_{P^{\prime}}$ 分布の $\eta_{k}=0$ および-1 における 境界值および式（23）の積分項は線形補間で評価した. 第二項の粗さ要素上の平均粘性応力 $\left\langle\tau_{0 v}\right\rangle_{w}^{+}$は本粗面流お よび $P R=2$ の粗面流(19)ではそれぞれ $\left\langle\tau_{0 v}\right\rangle_{w}^{+} \fallingdotseq 0.57$ および 1.66 であった. その結果を図 8 に示す. 図 8 中には本粗 面流および $P R=2$ の粗面流 ${ }^{(19)}$ の結果を合わせて示寸. 本粗面流の $\langle\tau\rangle_{c}^{+}$值は, 正值から溝内部底面に向かって減少

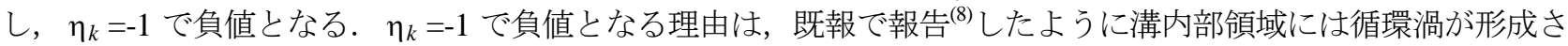
れ，それにより溝内部底面近傍の流れが逆流になるためである。.また, 図 8 中には本粗面流の溝内部で計測され た $U, V$ および- $\overline{u v}$ に基づいて評価された式（15）の結果を卵で示す. 速度計測值から評価された $\langle\tau\rangle_{c}^{+}$值は $\eta_{k}=0.5$ 付近まで $\Delta C_{P^{\prime}}$ 分布から評価された結果と良好に一致している. $\eta_{k}<-0.5$ の領域では, 溝内部底面に向か い徐々に $\Delta C_{P^{\prime}}$ 分布から評価された結果からずれている.この要因は, $\eta_{k}<-0.5$ の領域では溝内部側壁および溝部 
底面の存在により溝内部側壁面近傍領域のLDVによる速度計測が出来なかったためである。一方， $P R=2$ の粗面 流のそれは溝内部底面に向かって減少し, $\eta_{k} \doteqdot 0.4$ 付近で負の極小值をとった後増加するが, 溝内部底面では本 結果と同様に逆流のため負值となる. 以上より, $\langle\tau\rangle_{c}^{+}$分布は $\Delta C_{P^{\prime}}$ 值分布, 壁面抵抗に対する圧力抵抗の比 $R_{P}$ お よび粗さ要素頂上面の粘性抵抗 $\left\langle\tau_{0 v}\right\rangle_{w}^{+}$の $P R$ 值による差異に依存して変化する. 次に, 式 (16) に基づいて $\langle\tau\rangle_{c}^{+} に$ 対する各項の寄与を本粗面流について調查する. その結果を図 9 に示す. 各項は壁面せん断応力で無次元化され た. 式（16）の空間平均粘性応力および見かけのせん断応力項は, 測定最下端位置のデータを除いて 0.1 以下で あり, $\langle\tau\rangle_{c}^{+}$に対して空間平均レイノルズせん断応力項の寄与が大きい. 従って, $P R=4$ の粗面流では可視化害験

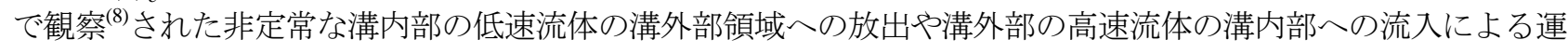
動量輸送が主となることが予想される．なお， $P R=2$ に関しては溝内部領域を詳細に測定された例がないため不 明であるが，溝内部流体の可視化観察 ${ }^{(8)}$ から推測すると $P R=4$ の場合に比較して非定常な挙動による運動量の輸 送頻度は約 0.4 倍と小さく, 溝内部には比較的安定な渦パターンが形成される. そのため, $\langle\tau\rangle_{c}^{+}$值に対して式 (16) の各項の寄与は $P R=4$ に比べて空間平均レイノルズせん断応力が減少し, 空間平均粘性応力や見かけのせん断応 力が増加すると考えられる. 以上より, 溝内部に形成される渦の非定常性に依存して式 (16) の各項の寄与率が $P R$ 值に対して変化し，それに伴い溝内部上流および下流側壁面の圧力差の大きさや分布形状に差異が生じると推測 される.

\section{4. 結言}

二次元矩形粗さ要素からなる粗面平板上に発達する平衡境界層の壁近傍において, LDV を使用して平均速度お よび乱流場を実測した．LDVによる取得データと壁近傍場における空間平均運動方程式の主要項から, 粗さ要素 溝内部側壁面の圧力分布に対する運動量輸送の影響を調査した. 以下に主な結果を示す.

(1) 粗さ要素一ピッチ当りで空間平均された運動方程式から, 粗さ要素近傍の粗さ底層の流れは高さ方向空間平 均せん断応力勾配が圧力抵抗に起因した溝内部上流と下流側壁面に作用する圧力の差と関連する領域とゼ ロとなる領域の 2 領域に分類される.

（2）溝内部領域を除く粗面壁近傍場において，空間平均された平均流線の波打ちによる見かけの応力，レイノル ズせん断応力および粘性応力の和は壁面せん断応力と等しくなり, $\eta_{k}=0$ において空間平均粘性応力および 平均流線の波打ち効果による見掛けの応力は $\left\langle\tau_{w}\right\rangle$ に対してそれぞれ $12.1 \%$ おび $8.8 \%$ の寄与である.

(3) 溝内部領域における空間平均せん断応力分布は溝内部上流および下流側壁面の圧力差分布, 壁面抵抗に対す る圧力抵抗の比や粗さ要素頂上面に作用する粘性応力に依存して変化し，その值は溝内部底面に向かい正か ら減少して溝内部底面で負となる. また, 空間平均せん断応力に対してレイノルズせん断応力の寄与が最も 大きく, レイノルズせん断応力による運動量輸送項が溝内部上流と下流側壁面の圧力差に主として関係する.

\section{謝 辞}

本研究は JSPS 科研費 18360091 の補助を受けたものです．また，本研究を遂行するに当たって風洞実験を行っ てくれた小西暢之君（現（株）三井造船）および星野智紀君（現（株）ダイキン工業）の両名に感謝致します.

\section{文献}

（1）亀田孝嗣，望月信介，大坂英雄，”粗面乱流境界層における壁面抵抗の作用点とそれに基づく壁法則の検討” 日本 機械学会論文集 B 編，Vol.73, No.733（2007），pp.1821-1828.

(2) Leonardi S., Orlandi P. and Antonia R.A., "Properties of d- and k-type Roughness in a Turbulent Channel Flow", Physics of Fluids, Vol.19 (2007) , 125101.

(3) Jackson P.S., "On the Displacement Height in the Logarithmic Velocity Profile", Journal of Fluid Mechanics, Vol.111 (1981), pp15-25.

(4) Morris H.M., "Design Methods for Flow in Rough Conduits", Journal of the hydraulics Division, Proceeding of the American Society of Civil Engineers, HY7 (1959) ,pp. 43-62. 
(5) 亀田孝嗣, 大坂英雄, 望月信介, ” $\mathrm{k}$ 形粗面境界層の粗さ要素近傍構造に対する粗さピッチ比の影響”, 日本機械学 会論文集 B 編，Vol.70, No.697（2004）, pp. 2303-2310.

(6) Towness H.W. and Sabersky R.H., "Experiments on the Flow over a Rough Surface", International Journal of Heat Mass Transfer, Vol.9 (1966) , pp.729-738.

(7) Djenidi L., Elavarasan R. and Antonia R.A., "The Turbulent Boundary Layer over Transverse Square Cavities", Journal of Fluid Mechanics, Vol.395 (1999) , pp.271-294.

(8) 亀田孝嗣, 是石一任, 望月信介, 大坂英雄, ” 二次元矩形粗面境界層の粗さ要素近傍における運動量交換機構（溝 内部渦の可視化観察)”，日本機械学会論文集 B 編，Vol.71, No.710（2005）, pp.2401-2406.

(9) Leonardi S., Orlandi P., Smally R.J., Djenidi L. and Antonia R.A., "Direct Numerical Simulations of Turbulent Channel Flow with Transverse Square Bars on One Wall", Journal of Fluid Mechanics, Vol.491（2003） , pp.229-238.

(10) Bandyopadhyay P.R. and Watson R.D., "Structure of Rough-wall Turbulent Boundary Layers", Physics of Fluids, Vol.31, No.7 (1988) , pp.1877-1883.

(11) Napoli E., Armenio V. and De Marchis M., "The effect of the Slope of Irregularly Disturbed roughness Elements on Turbulent Wall-bounded Flows", Journal of Fluid Mechanics, Vol.613 （2008） , pp. 385-394.

(12) Schultz M.P. and Flack K.A., "Turbulent Boundary Layers on a Systematically Varied Rough Wall", Physics of Fluids, Vol.21 (2009) , 015104.

（13）亀田孝嗣，望月信介，大坂英雄，檜垣克哉，”完全相似条件を満足する粗面乱流境界層の実現とその平均流特性”, 日本機械学会論文集 B 編, Vol.72，No.717 (2006)，pp.1166-1173.

(14) Osaka H., Kameda T. and Mochizuki S., "Re-examination of the Reynolds-Number-Effect on the Mean Flow quantities in a Smooth Wall Turbulent Boundary Layer”, JSME International Journal, Series B, Vol.41, No.1（1998） , pp.123-129.

(15) 亀田孝嗣, 大坂英雄, 望月信介, ” $\mathrm{k}$ 形粗面乱流境界層の粗さ要素近傍構造”, 日本機械学会論文集 B 編, Vol.66, No.646 (2000), pp.1347-1355.

(16) Pokrajac D., Campbell L.J., Nikora V., Manes C. and McEwan I., "Quadrant Analysis of Persistent Spatial Velocity Perturbations over Square-bar Roughness”, Experiments in Fluids, Vol.42 （2007）, pp.413-423.

(17) Perry A.E., Lim K.L. and Henbest S.M., "An Experimental Study of the Turbulent Structure in Smooth- and Rough-wall Boundary Layer", Journal of Fluid Mechanics, Vol.177 (1987） , pp.437-466.

(18) 亀田孝嗣, 大坂英雄, 望月信介, ”k 形粗面境界層の粗さ要素近傍における乱流輸送機構”, 日本機械学会論文集 B 編, Vol.69, No.686 (2003), pp.2260-2267.

(19) 大坂英雄, 坂本雅巳, 影山芳朗, ”d形粗面上の乱流境界層のあらさ要素近傍特性”, 日本機械学会論文集 B編, Vol.52, No.478 (1986), pp.2360-2366.

(20) Schofield W.H., Perry A.E. and Joubert P.N., "Similarity Relations for Pressure Distributions on Slot Type Rough Walls under Turbulent Boundary Layers", Journal of Fluids Engineering, Transaction of ASME, Vol.96 （1974）, pp.186-188. 